University of Nebraska - Lincoln

DigitalCommons@University of Nebraska - Lincoln

Qualitative and quantitative analysis of lignocellulosic biomass using infrared techniques: A mini-review

\author{
Feng Xu \\ Kansas State University \\ Jianming $\mathrm{Yu}$ \\ Kansas State University, jmyu@iastate.edu \\ Tesfaye Tesso \\ Kansas State University \\ Floyd Dowell \\ USDA-ARS \\ Donghai Wang \\ Kansas State University, dwang@ksu.edu
}

Follow this and additional works at: https://digitalcommons.unl.edu/usdaarsfacpub

Xu, Feng; Yu, Jianming; Tesso, Tesfaye; Dowell, Floyd; and Wang, Donghai, "Qualitative and quantitative analysis of lignocellulosic biomass using infrared techniques: A mini-review" (2013). Publications from USDA-ARS / UNL Faculty. 1227.

https://digitalcommons.unl.edu/usdaarsfacpub/1227

This Article is brought to you for free and open access by the U.S. Department of Agriculture: Agricultural Research Service, Lincoln, Nebraska at DigitalCommons@University of Nebraska - Lincoln. It has been accepted for inclusion in Publications from USDA-ARS / UNL Faculty by an authorized administrator of DigitalCommons@University of Nebraska - Lincoln. 


\title{
Qualitative and quantitative analysis of lignocellulosic biomass using infrared techniques: A mini-review
}

\author{
Feng $\mathrm{Xu}^{\mathrm{a}}$, Jianming $\mathrm{Yu}^{\mathrm{b}}$, Tesfaye Tesso ${ }^{\mathrm{b}}$, Floyd Dowell ${ }^{\mathrm{c}}$, Donghai Wang ${ }^{\mathrm{a}, *}$ \\ a Department of Biological and Agricultural Engineering, Kansas State University, Manhattan, KS 66506, USA \\ ${ }^{\mathrm{b}}$ Department of Agronomy, Kansas State University, Manhattan, KS 66506, USA \\ ' USDA-ARS, Center for Grain and Animal Health Research, 1515 College Avenue, Manhattan, KS 66502, USA
}

\section{H I G H L I G H T S}

Infrared techniques are fast, accurate, and low-cost for biomass analysis.

- A comparison of infrared techniques and chemical method is made.

- Chemometric analaysis provides prediction model for composition analysis.

\section{A R T I C L E I N F O}

\section{Article history:}

Received 4 September 2012

Received in revised form 4 December 2012

Accepted 5 December 2012

Available online 2 January 2013

\section{Keywords:}

Infrared spectroscopy

Biomass

Cellulose

Lignin

Chemometric analysis

\begin{abstract}
A B S T R A C T
Current wet chemical methods for biomass composition analysis using two-step sulfuric acid hydrolysis are time-consuming, labor-intensive, and unable to provide structural information about biomass. Infrared techniques provide fast, low-cost analysis, are non-destructive, and have shown promising results. Chemometric analysis has allowed researchers to perform qualitative and quantitative study of biomass with both near-infrared and mid-infrared spectroscopy. This review summarizes the progress and applications of infrared techniques in biomass study, and compares the infrared and the wet chemical methods for composition analysis. In addition to reviewing recent studies of biomass structure and composition, we also discuss the progress and prospects for the applications of infrared techniques.
\end{abstract}

(c) 2012 Elsevier Ltd. All rights reserved.

\section{Contents}

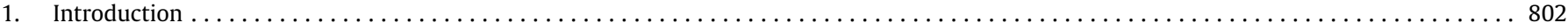

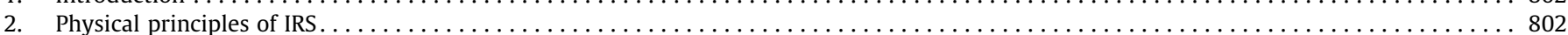

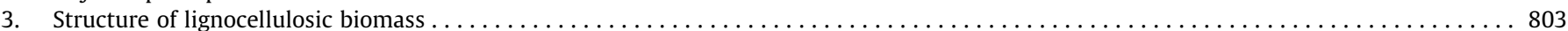

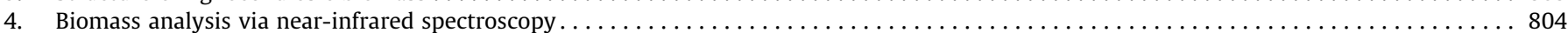

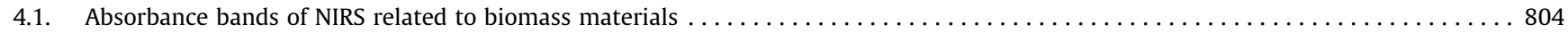

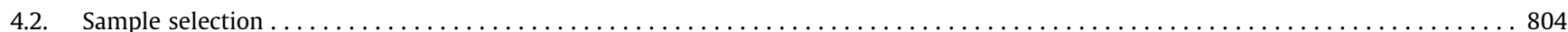

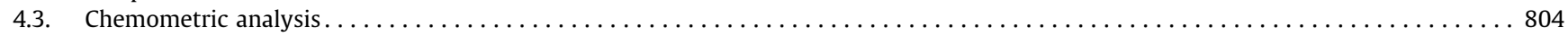

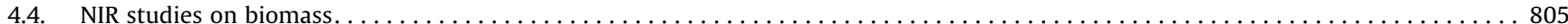

5. Biomass analysis via Fourier transform mid-infrared spectroscopy $\ldots \ldots \ldots \ldots$

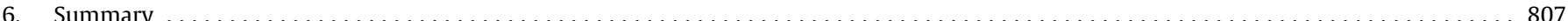

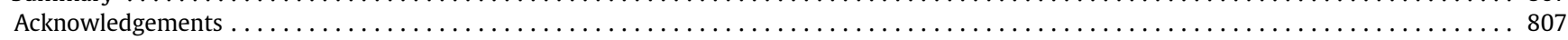

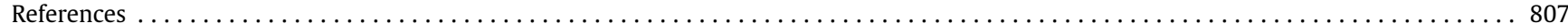

\footnotetext{
* Corresponding author. Tel.: +1 785532 2919; fax: +1 7855325825

E-mail address: dwang@ksu.edu (D. Wang).
} 


\section{Introduction}

Lignocellulosic biomass has become an alternative source for production of chemicals and fuels because it is renewable and could reduce greenhouse gas emissions by replacing petroleum sources [1]. The major components of lignocellulosic biomass are cellulose, hemicellulose, and lignin. Cellulose and hemicellulose are polysaccharides, which could be hydrolyzed to molecules via a relatively low degree of polymerization for further biological/ chemical utilization [2]. The next generation of cellulosic ethanol is being developed from these polysaccharides with microbial fermentation [3,4]. Lignin, a phenolic polymer, is also an important source for industrial applications such as adhesive resin $[5,6]$ and lignin gels [7,8]. Lignin and cellulose are being developed for the synthesis of biodegradable polymers [9]. Biomass composition varies by variety and production location/conditions [10], which, in turn, significantly affects processing strategies. For example, alkali pretreatment is more effective with low lignin-content biomass [11]. Biomass composition also changes significantly during biomass processing [12], so a fast and accurate determination of biomass composition is critical for accelerating biomass utilization.

Classic wet chemical methods for biomass determination, which employ a two-step sulfuric acid hydrolysis, have been used for over a century, and improvements have adapted them to different objects and conditions $[13,14]$. The National Renewable Energy Laboratory also distributed a series of procedures for biomass determination that have become the de facto procedures for biomass application [15]. Standard wet chemical methods provide reliable information about biomass composition and have been proven to work well with both wood and herbaceous feedstock, but they are labor-intensive and time-consuming, which make them inappropriate for industrial applications or large numbers of samples; for example, a complete analysis using wet chemical methods costs $\$ 800-2000$ per sample [16]. Recent developments in the wet chemical method include a small-scale, high-throughput method that is able to process a large number of samples in reduced time [17]. However, besides the additional costs of the instruments/devices (e.g., powder/liquid-dispensing system), these methods still need development because some components of biomass (e.g., acid-soluble lignin and ash) are not determined. Other disadvantages of the wet chemical methods are that they require pre-conditioning to remove extractives, and they generate reliable results only from samples within a certain range of particle size [18]. In addition, chemical methods are not able to differentiate among types of hemicellulose, such as xyloglucan and arabinoxylan [19]. Thus, a reliable low-cost, time-saving method is urgently needed for biomass analysis.
Infrared spectroscopy (IRS) has been widely used for qualitative and quantitative analysis in various areas such as the food and pharmaceutical industries [20-23]; for example, the composition of protein and oil in meat products, cereal crops, and food products was predicted successfully using near-infrared spectroscopy (NIRS) [24-26], as were Brix value and starch content in fruits [27]. The cost of analysis of grain materials using NIRS ( $\$ 13$ per sample) is lower than that using feed analysis (over $\$ 17$ per sample) [28]. Infrared spectroscopy also has been proven able to produce qualitative and quantitative results for biomass application [16,29]; for example, Fourier transform infrared spectroscopy (FTIR) has been used successfully for compositional analysis of lignocellulosic biomass [30]. The main advantages of IRS technology are that sample preparation is simple, analysis is fast and precise, and many constituents can be analyzed at the same time. Thus, the cost of biomass sample analysis could be reduced to about $\$ 10$ for each sample [16]. One exclusive characteristic of the IRS method is that it is non-destructive, so the sample could be used for other analysis after IRS measurement. IRS analysis also uses no hazardous chemicals. A comparison of IRS and wet chemical methods on biomass analysis is shown in Fig. 1. In addition to the determination of the major polysaccharides in biomass, IRS is capable of providing other structural information. Although numerous chemicals or reagents, such as enzymes and alkali, could be used to extract the polymeric components in plant cell walls, the complicated crosslinkages between the polymer chains may not be well elucidated by chemical extraction. The IRS techniques could be used for composition and structural analysis, such as detection of functional groups [31]. Only a few studies have been reported for the determination of biomass composition, because earlier IRS analysis suffered from blanket absorption of water [32], but the development of Fourier transform data processing and computer modeling could solve this problem.

To date, a critical review of IRS application on biomass analysis is not available. This review, in addition to summarizing the basic principle of IRS and the characterization of biomass, discusses the applications of IRS in biomass utilization.

\section{Physical principles of IRS}

Infrared spectroscopy is usually a result of the fundamental molecular vibration mechanism, which refers to energy-matter interaction [33]. Upon an interaction of the IR radiation with an oscillating dipole moment associated with a vibrating bond, the absorption of the radiation corresponds to a change of the dipole moment. Generally, different functional groups correspond to dif-

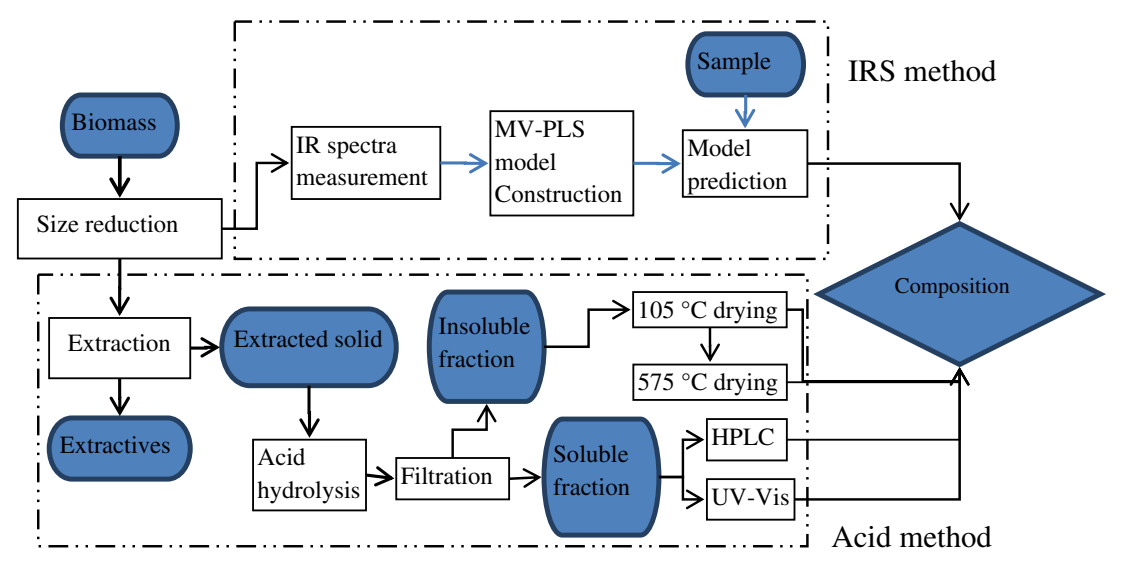

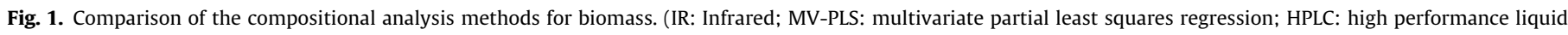
chromatography; UV-Vis: ultraviolet-visible spectroscopy.). 

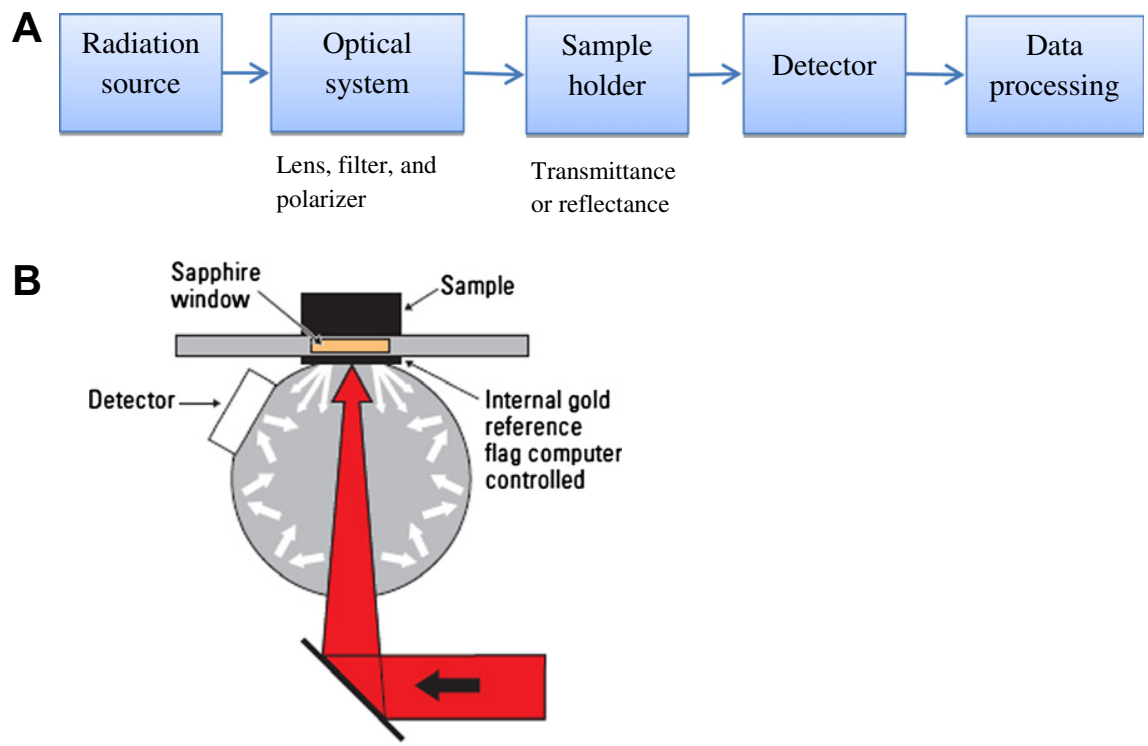

Fig. 2. (A) Block diagram of infrared measurement system and (B) diagram of Thermo NIR integrating sphere (Image courtesy of Thermo scientific).

ferent components of the IR spectrum; therefore, the spectral features could be used for structural analysis. The infrared region consists of three regions according to wavelength range: nearinfrared $\left(780-2500 \mathrm{~nm}\right.$ or $\left.12800-4000 \mathrm{~cm}^{-1}\right)$, mid-infrared $\left(2500-25,000 \mathrm{~nm}\right.$ or $\left.4000-400 \mathrm{~cm}^{-1}\right)$, and far-infrared $(25,000-$ $1000,000 \mathrm{~nm}$ or $400-10 \mathrm{~cm}^{-1}$ ) [34]. Mid-infrared is used to investigate the fundamental vibrations and related structures, whereas near-infrared analysis provides information on molecular overtones and combinations of vibrations. One interesting feature in NIRS is the overtone, which consists of numerous combinations of vibrational bands. Even for some simple molecules with few fundamental vibration modes, many overtone bands could be shown in NIR spectra, depending on various combinations; chloroform, for example, has six fundamental modes but about 34 overtone modes [34]. Although the NIR spectra appear complicated, they are not a random mix, which makes it possible to analyze structure information with chemometric techniques.

The components of the IRS system usually include lenses, a radiation source, filters, a detector, and a data processing unit (Fig. 2A) [35]. The filter system is used to define wavelength range, which makes it a crucial component in the infrared system. Several types of filters are available: fixed filters, variable filters, and tilting filters. IRS typically measures light absorption, and light reflectance mode is used for solid biomass [16]. Attenuated total reflectance (ATR) is widely used with FTIR in biomass measurement, which simplifies sample preparation. In the NIR system, a diffuse reflection approach in use is an integrating sphere (Fig. 2B), in which light is directed onto a sample. The integrating sphere is suitable for measuring inhomogeneous samples such as biomass material (e.g., stover, wood chips) because the sampling area is large. Numerous NIR systems have been developed for applications from indoor laboratory to field uses; for example, a field spectrometer has been developed that can be carried in a backpack [36], and remote techniques can be coupled with outdoor spectrometers for field monitoring [37].

To date, a computerized spectrophotometry system has been widely used to perform advanced investigation. With a combination of microscopy and spectroscopy, FTIR could be used to quantify the chemical composition of microscopic samples [38]. Both FTIR and NIR imaging techniques that provide spatially resolved chemical information have been applied in pharmaceutical $[39,40]$ and food industry [41]. The imaging techniques are helpful for better understanding biomass structure. For example, in situ FTIR microscopic was employed to monitor the structural changes of native plan cell walls with enzymatic treatment [42]. With this technique, it is possible to reveal the intrinsic mechanism of enzymatic hydrolysis and the biomass recalcitrance to enzyme. More study of biomass structure with infrared microscopy is suggested.

\section{Structure of lignocellulosic biomass}

Lignocellulosic biomass has become a promising alternative source of materials for industrial applications [9]. The major component of most biomass, such as sorghum biomass, is plant cell wall. Plant cell wall naturally protects the cell from outside erosion and allows turgor. Different layers of the cell wall play different roles and perform special physiological functions [43]. For example, the primary wall, which contains $1-10 \%$ cellulose, allows cell expansion, and the secondary wall provides a barrier against potential pathogens [44]. The major components of the plant cell wall are cellulose, hemicellulose, and lignin, in which cellulose and hemicellulose are generally referred to as polysaccharides.

Cellulose (molecular formula, $\left.\left(\mathrm{C}_{6} \mathrm{H}_{10} \mathrm{O}_{5}\right)_{n}\right)$ is one of the most important polysaccharides in the plant cell wall and has been widely used in the paper industry [45]. With an ordered structure in the plant cell wall, cellulose consists of hundreds of glucose molecules linked by glucosidic linkage [46]. The glucan chains are usually connected by hydrogen bonds to form microfibrils in the cell wall. There are 4 different types of cellulose (I, II, III, and IV) [47], and cellulose I is considered native cellulose. FTIR is widely used to study native cellulose; for example, FTIR was employed to study the conversion from cellulose I $\alpha$, which is enriched in some microbes, to I $\beta$, which is found primarily in plant cell wall [48]. Naturally, the two types of cellulose I co-exist in the plant cell wall in different proportions depending on the plant species. Cellulose has both a well-ordered structure and a randomly ordered structure, or crystalline and amorphous structure, respectively. FTIR is an efficient method to study crystallinity, and the hydrogen-bonding formation in amorphous cellulose has been investigated by FTIR [49]. The specially ordered structure of cellulose in the fiber system, or the distribution of cellulose orientation, also can be studied by dynamic FTIR [50]. 
Hemicellulose is another polysaccharide that usually contains much more complicated structure and linkages than cellulose. Naturally, hemicellulose is connected with cellulose microfibrils by non-covalent linkages [51], and hemicellulose generally consists of more than one type of monosaccharide unit, including both hexose and pentose. Depending on the variety of biomass, hemicellulose may contain xyloglucan, xylan $\left(\left(\mathrm{C}_{5} \mathrm{H}_{8} \mathrm{O}_{4}\right)_{n}\right)$, glucomannans, galactoglucomannans, etc. The detailed structure of hemicellulose remains unknown, and IRS is one method that could be used to reveal its structural secrets [52]. Coupled with thermogravimetric analysis, FTIR has been employed to investigate the mechanism of the hemicellulose pyrolysis [53].

Lignin is made of phenolic polymers that consist of three types of phenylpropane untis: p-coumaryl alcohol, coniferyl alcohol, and sinapyl alcohol [54]. Because the native structure of lignin is very complicated and usually plays a negative role during monosaccharides production from biomass [55], different techniques have been employed to understand how lignin affects biomass processing [56]. Traditionally, lignin has been measured with time-consuming and labor-intensive methods [57]. The analytical methods along with IRS could provide a rapid and low-unit-cost solution for lignin measurement. For example, FTIR investigation of various lignin model compounds was conducted and explained the different hydrogen-bonding systems between hardwood and softwood [58].

\section{Biomass analysis via near-infrared spectroscopy}

The applicability of NIR for biomass analysis was revealed in the last decade $[16,59]$. Although the throughput is essential in the mid-IR region, bright sources have become available in the NIR region, so wavelength resolution is not an issue [60]. The NIR measurement is non-destructive and can be completed within milliseconds. A pre-constructed computer model could automatically analyze the NIRS data and perform predictions. Online NIR could allow real-time quality control of substrate and monitoring biomass processing. FT-NIR provides spectra with high resolution without degradation of optical throughput [61].

\subsection{Absorbance bands of NIRS related to biomass materials}

For biomass analysis, related NIR absorption bands are assigned before an initial calibration process. Previous study of wood samples suggested a high degree of inter-correlation between the absorption bands [62]. After recognition of the fundamental bands, a combination of bands could be used for calibration. Table 1 sum-

Table 1

Near-infrared major absorbance bands for biomass (eucalyptus) analysis; adapted from [99].

\begin{tabular}{lll}
\hline $\begin{array}{l}\text { Wavelength } \\
(\mathrm{nm})\end{array}$ & Bond vibration & $\begin{array}{l}\text { Related } \\
\text { structure }\end{array}$ \\
\hline 1520 & O-H stretch first overtone & $\mathrm{CONH}_{2}$ \\
1616 & C-H stretch first overtone & $\mathrm{CH}_{2}$ \\
1688 & C-H stretch first overtone & Aromatic \\
1724 & C-H stretch first overtone & $-\mathrm{CH}_{2}$ \\
1740 & S-H stretch first overtone & $-\mathrm{SH}$ \\
1782 & C-H stretch first overtone & Cellulose \\
1896 & O-H stretch C-O stretch & $\mathrm{C}=\mathrm{O}, \mathrm{CO}_{2} \mathrm{H}$ \\
1910 & O-H stretch first overtone & $\mathrm{Ar}-\mathrm{OH}$ \\
2028 & C=O stretch second overtone & CONH \\
2074 & N-H2 deformation second overtone & Amide II \\
2266 & O-H C-O combination bands & Cellulose \\
2332 & C-H stretch, C-H deformation & Cellulose, \\
& & starch \\
2386 & C-O stretch O-H deformation second & Primary \\
& overtone & alcohols \\
\hline
\end{tabular}

marizes the reported results of absorption bands from woody biomass. Because the absorption bands in NIR cover a large amount of information and, depending on the objective, only part of the spectra may be needed for model construction, a model with reduced spectral range works well; for example, a model to measure chemical properties of wood has a correlation coefficient over 0.9 [63]. Recognizing and selecting a useful spectral range is critical because it also saves the cost of determination.

\subsection{Sample selection}

Sample selection is critical, because informative samples could provide adequate variance for analysis. All parameters that could affect sample properties should be considered in sample selection procedure. For example, samples from different production locations or times should be included in the calibration/validation set even though one is studying other parameters. For investigated parameters, the data range obtained from the reference method (e.g., the wet chemical method in composition determination) should be wide and smooth, avoiding too many samples with similar concentrations on certain parameters. At least 100 reference samples with adequate variances could generate a robust model. Sample number also could be determined by the number of the concerned parameter [64]. For example, at least 10 samples are necessary for each independent parameter. American Society for Testing and Materials (ASTM) International also provides guidelines for sample calibration. The particle size of a powder sample influences NIR reflectance, but an adjustment of particle size before measurement is not necessary because the effect could be calibrated by signal correction with software.

\subsection{Chemometric analysis}

Because IR spectra contain robust information about chemical bonds, compositional information is not directly available from their results [65]; thus, chemometric techniques, such as multivariate models, are necessary for spectra analysis. By reducing the large amount of spectral data in several latent variables, the statistical methods/models could build a relationship between spectral features and chemical components/bonds. Previous studies also demonstrated the successful application of chemometric analysis (e.g., principle component analysis (PCA) and partial least squares (PLS)) on the determination of biomass components [66].

After NIR measurement, chemometric analysis usually includes calibration, validation, and prediction (Fig. 3). Data treatment before calibration is helpful. For example, derivatives are usually employed in cases with overlapping peaks and baseline variation [67]. It should be noted that although derivatives are valuable, they sometimes generate false information. Michell [68] found that the second derivative form was not always more precise than the normal form for lignin prediction in a wood study.

The calibration procedure in NIR analysis is to build relationships between NIR data and reference values. For quantitative analysis of biomass, a complete understanding of the sources of NIRS data is not necessary, because the calibration methods for modeling the spectra would extract related information. Since the optical response (e.g., reflectance) to chemical composition is not linear, multivariate regression is usually employed [64]. Different statistical methods could be used for calibration $[69,70]$. The data processing/conditioning of NIRS results could be performed with statistical software such as Matlab. Most NIR instruments come with compatible software packages. For example, the FTNIR system Antaris II (Thermo-Fisher Sci. Inc.) comes with TQ Analyst software that contains the PLS/PCA function, which could be used for modeling and prediction. Once a calibration model is obtained, it is also important to update it periodically. To date, differ- 


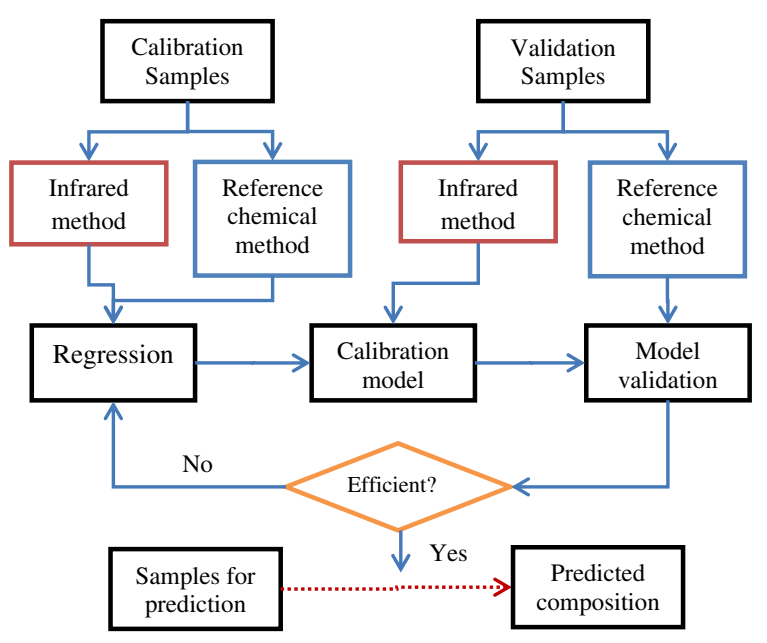

Fig. 3. Flow chart of calibration and validation process.

ent calibration models have been developed for various biomass samples. Jin and Chen [71] obtained a successful prediction of total ash, insoluble ash, moisture, cellulose, hemicellulose, and Klason lignin in rice straw. After calibration, another set of samples, the external validation set, usually is prepared for validation to compare the predicted values from the calibration model and those from the reference method. Cross validation also is employed in case the number of available calibration samples is small [72]. Evaluation of model could be performed with parameters given by software, such as correlation coefficient $\left(R^{2}\right)$ (Table 2 ) and root mean squared error of cross validation (RMSECV).

\subsection{NIR studies on biomass}

Among studied biomass materials, woody biomass has been reported frequently in compositional studies with NIR. In the wood and paper industry, NIRS has been used to study the physical properties of wood, such as density and compression, in addition to chemical composition [73,74]. Other physical properties, such as mechanical properties, also could be investigated via NIRS, and a reduced spectral range $(650-1150 \mathrm{~nm})$ was used successfully for prediction [75]. The NIRS method is also a powerful tool for predicting other properties, such as moisture, ash, and char content [76,77], which is helpful in evaluating biomass processing. Real-time monitoring of biomass composition is important for industrial applications, because the composition of

Table 2

Chemometric analysis of different biomass samples using infrared spectroscopy.

\begin{tabular}{|c|c|c|c|c|c|}
\hline Biomass & $\begin{array}{l}\text { Wavelength } \\
\text { region }(\mathrm{nm})\end{array}$ & $\begin{array}{l}\text { Accuracy of } \\
\text { calibration model (R2) }\end{array}$ & $\begin{array}{l}\text { Accuracy of } \\
\text { prediction model }\left(R^{2}\right)\end{array}$ & Modeling methods & Data source \\
\hline \multicolumn{6}{|l|}{ Lignin } \\
\hline Decaying forest foliage & $1100-2000$ & 0.91 & 0.87 & $\begin{array}{l}\text { Stepwise forward } \\
\text { multiple linear regression }\end{array}$ & {$[100]$} \\
\hline Forest floor (fresh leaf, litterfall) & $1100-2500$ & 0.91 & 0.87 & $\begin{array}{l}\text { Stepwise multiple } \\
\text { linear regression }\end{array}$ & {$[101]$} \\
\hline Pulpwood & $1100-2500$ & 0.97(Std), 0.93(PLS) & NA & PCA, PLS ${ }^{a}$ & [68] \\
\hline Woody and herbaceous biomass & $1100-2500$ & 0.97 & 0.99 & PLS & {$[81]$} \\
\hline Woody biomass & $400-2500$ & NA & 0.98 & PLS & {$[80]$} \\
\hline Wood & $400-2500$ & 0.85 & 0.87 & PCA,PLS & [99] \\
\hline Poplar & $5500-11000$ & 0.91 & 0.88 & PCA, PLS & [102] \\
\hline \multirow[t]{2}{*}{ Yellow poplar } & $800-2500$ & 0.81 & 0.66 & PCA, PLS & [103] \\
\hline & $1300-1800$ & 0.68 & 0.77 & & \\
\hline Wood (pine) & $600-1900$ & 0.99 & 0.72 & PLS & {$[104]$} \\
\hline Wood & $500-2400$ & 0.81 & 0.76 & PLS & {$[75]$} \\
\hline Softwood residue & 5417-15527 & 0.98 & NA & PLS & [30] \\
\hline Wood (E. globulus) & NA & 0.76 & 0.67 & NA & {$[105]$} \\
\hline Corn stover & $1000-2500$ & 0.94 & NA & PLS & {$[82]$} \\
\hline Corn stover & $400-2500$ & 0.85 & Cross Validation & PLS & [79] \\
\hline Rice straw & $1000-2500$ & 0.89 & 0.86 & PLS & {$[71]$} \\
\hline Agricultural fiber & $500-2400$ & 0.88 & 0.71 & PCA,PLS & {$[106]$} \\
\hline \multicolumn{6}{|l|}{ Glucan } \\
\hline \multirow[t]{2}{*}{ Wood } & $500-2400$ & 0.90 & 0.78 & PLS PCA & {$[75]$} \\
\hline & $650-1150$ & 0.88 & 0.84 & & \\
\hline Woody biomass( $\alpha$-cellulose) & $400-2500$ & 0.98 & 0.97 & PLS & {$[80]$} \\
\hline Agricultural fiber & $500-2400$ & 0.94 & 0.87 & PLS PCA & {$[106]$} \\
\hline Corn stover & $1000-2500$ & 0.97 & NA & PLS & {$[82]$} \\
\hline Corn stover & $400-2500$ & 0.68 & Cross Validation & PLS & [79] \\
\hline Rice straw & $1000-2500$ & 0.93 & 0.93 & PLS & [71] \\
\hline Decaying forest foliage & $1100-2000$ & 0.90 & 0.84 & $\begin{array}{l}\text { Stepwise forward } \\
\text { multiple linear regression }\end{array}$ & {$[100]$} \\
\hline Forest floor (fresh leaf, litterfall) ${ }^{b}$ & $1100-2500$ & 0.88 & 0.83 & $\begin{array}{l}\text { Stepwise multiple } \\
\text { linear regression }\end{array}$ & {$[101]$} \\
\hline \multicolumn{6}{|l|}{ Xylan } \\
\hline Corn stover & $1000-2500$ & 0.93 & NA & PLS & {$[82]$} \\
\hline Corn stover & $400-2500$ & 0.81 & Cross Validation & PLS & [79] \\
\hline Woody and herbaceous biomass & $1100-2500$ & 0.98 & 0.99 & PLS & {$[81]$} \\
\hline \multirow[t]{2}{*}{ Wood } & $500-2400$ & 0.80 & 0.56 & PLS & [75] \\
\hline & $650-1150$ & 0.80 & 0.54 & & \\
\hline Agricultural fiber & $500-2400$ & 0.87 & 0.71 & PLS PCA & [106] \\
\hline Straw & $1100-2500$ & 0.88 & 0.86 & Modified PLS & [107] \\
\hline Rice straw & $1000-2500$ & 0.91 & 0.91 & PLS & {$[71]$} \\
\hline
\end{tabular}

a PLS represents partial least squares; PCA represents principal component analysis.

$\mathrm{b}$ The analysis is conducted based on holocellulose. 
biomass may vary according to location and variety. Online monitoring of wood chips and bark was realized with NIR coupled with a silicon diode array spectrometer, which measured the extractives, Klason lignin, and size distribution [63]. Instead of woody biomass, several herbaceous feedstocks, such as corn stover and switchgrass, have been studied using NIRS. Hames et al. [16] employed NIRS/PLS for compositional analysis of corn stover and suggested a good prediction for glucan, xylan, lignin, protein, and ash. Similar studies also reported good prediction for major components of corn stover $[78,79]$.

The composition of the major components of biomass has been modeled with NIRS. Lignin composition has been studied extensively by NIR and FTIR (Table 2). Wood lignin has been investigated in detail; most calibration models have a correlation coefficient larger than 0.8 , and most prediction models have a correlation coefficient larger than 0.7. Table 2 (glucan) summarizes the glucan analysis using NIR. Although different wavelength regions and modeling methods were used, most of the calibration models showed a high correlation between results from chemical methods and NIR data and relatively high accuracy of prediction $\left(R^{2}>0.8\right)$. For xylan analysis (Table 2 ), the results from literature review showed that most of the calibration models had a correlation factor larger than 0.8 , but the accuracy of prediction models varied. Hemicellulose is known to have a branched amorphous structure in the plant cell wall [51], and xylan is just one of the polysaccharides in hemicellulose. More investigation is needed to model the compositions of other polysaccharides, such as arabinose and mannose. Recent attention has been given to monitoring the structure/ composition changes of biomass during processing, and NIRS is being used as one of the techniques for structural study. For example, enzymatic digestibility of woody biomass and its compositional properties were well related in an integrated NIR method [80]. This efficient and accurate method could be used to evaluate processing efficiency.

Although NIRS provides fast and reliable results for biomass analysis, attention should be paid when using NIRS. First, a large population (over 100 samples) is usually preferred to develop robust calibrations [71,81], although studies have been reported with fewer than 100 samples for calibration [79,82]. Second, calibration conducted in a certain population, such as in targeted species, could improve accuracy and precision. Third, NIRS is unable to probe the information of trace elements, non-structural components, and those compounds with a concentration less than $1 \mathrm{~g} / \mathrm{L}$ (or $1 \mathrm{~g} / \mathrm{Kg}$ ) [16,29]. For IR radiation, only strongly polarized asymmetric chemical bonds give rise to intense bands; thus, supplementary techniques such as Raman spectroscopy, may serve to detect non-polar but polarizable bonds [83].

\section{Biomass analysis via Fourier transform mid-infrared spectroscopy}

Fourier transform mid-infrared spectroscopic analysis is also a rapid and non-destructive technique for the qualitative and quantitative determination of biomass components in the mid-IR region [30]. The high IR background absorbance of water is an obstacle when FTIR is employed in the analysis of wet solid biomass, but ATR-FTIR allows attenuation of the incident radiation and provides IR spectra without the water background absorbance. Sample preparation is critical, because FTIR works well with individual components extracted from the plant cell wall [84]. As mentioned above, NIR provides structural information by studying overtone peaks, whereas FTIR provides information about certain components in the plant cell wall through absorbance bands [85]. Table 3 summarizes absorbance bands corresponding to the functional groups in biomass materials.
Table 3

FTIR absorbance bands in biomass study; adapted from $[19]^{\mathrm{a}}[108]^{\mathrm{b}}[58]^{\mathrm{c}}$.

\begin{tabular}{|c|c|c|}
\hline $\begin{array}{l}\text { Wavenumber } \\
\left(\mathrm{cm}^{-1}\right)\end{array}$ & Assignment/functional group & Polymer \\
\hline 875 & Glycosidic linkage & Hemicellulose $^{\mathrm{a}}$ \\
\hline 930 & Glycosidic linkage & Cellulose, hemicellulose ${ }^{a}$ \\
\hline 990 & $\mathrm{C}-\mathrm{O}$ valence vibration & Cellulose $^{\mathrm{b}}$ \\
\hline 1035 & $\begin{array}{l}\mathrm{C}-\mathrm{O}, \mathrm{C}=\mathrm{C} \text {, and } \mathrm{C}-\mathrm{C}-\mathrm{O} \\
\text { stretching }\end{array}$ & $\begin{array}{l}\text { Cellulose, hemicellulose, } \\
\text { lignin }^{\mathrm{a}}\end{array}$ \\
\hline 1160 & $\begin{array}{l}\mathrm{C}-\mathrm{O}-\mathrm{C} \text { asymmetrical } \\
\text { stretching }\end{array}$ & Cellulose, hemicellulose $\mathrm{e}^{\mathrm{a}}$ \\
\hline 1200 & $\mathrm{O}-\mathrm{H}$ bending & Cellulose, hemicellulose ${ }^{a}$ \\
\hline 1215 & $\mathrm{C}-\mathrm{C}+\mathrm{C}-\mathrm{O}$ stretch & Lignin $(\text { wood })^{c}$ \\
\hline 1270 & Aromatic ring vibration & Guaicyl lignin ${ }^{a}$ \\
\hline 1280 & $\mathrm{C}-\mathrm{H}$ bending & Crystalline cellulose $^{\mathrm{a}}$ \\
\hline 1310 & $\mathrm{CH} 2$ wagging & Cellulose, hemicellulose ${ }^{a}$ \\
\hline 1327 & $\mathrm{C}-\mathrm{O}$ of syringyl ring & Lignin $(\text { wood })^{\mathrm{c}}$ \\
\hline 1335 & $\begin{array}{l}\mathrm{C}-\mathrm{H} \text { vibration, } \mathrm{O}-\mathrm{H} \text { in-plane } \\
\text { bending }\end{array}$ & $\begin{array}{l}\text { Cellulose, hemicellulose, } \\
\text { lignin }^{\mathrm{a}}\end{array}$ \\
\hline 1380 & $\mathrm{C}-\mathrm{H}$ bending & $\begin{array}{l}\text { Cellulose, hemicellulose, } \\
\text { lignin a }\end{array}$ \\
\hline 1425 & $\mathrm{C}-\mathrm{H}$ in-plane deformation & Lignin $(\text { wood })^{c}$ \\
\hline 1440 & $\mathrm{O}-\mathrm{H}$ in-plane bending & $\begin{array}{l}\text { Cellulose, hemicellulose, } \\
\text { lignin }^{\mathrm{a}}\end{array}$ \\
\hline 1465 & $\mathrm{C}-\mathrm{H}$ deformation & Lignin $^{\mathrm{a}}$ \\
\hline 1500 & Aromatic ring vibration & Lignin $^{a}$ \\
\hline 1595 & $\begin{array}{l}\text { Aromatic ring } \\
\text { vibration }+\mathrm{C}=\mathrm{O} \text { stretch }\end{array}$ & Lignin $^{\mathrm{a}}$ \\
\hline 1682 & $\begin{array}{l}\mathrm{C}=\mathrm{O} \text { stretching } \\
\text { (unconjugated) }\end{array}$ & Lignin $(\text { wood })^{\mathrm{c}}$ \\
\hline 1730 & Ketone/aldehyde $\mathrm{C}=\mathrm{O}$ stretch & Hemicellulose $^{\mathrm{a}}$ \\
\hline 1750 & Free ester & Hemicellulose $^{a}$ \\
\hline 2840, 2937 & $\mathrm{C}-\mathrm{H}$ stretching & Lignin $(\text { wood })^{c}$ \\
\hline 3421 & $\mathrm{O}-\mathrm{H}$ stretching & Lignin $(\text { wood })^{c}$ \\
\hline
\end{tabular}

Until now, FTIR has been widely employed to study either the individual components or the structure of biomass. Onion is one of the most popular substrates used in FTIR. The net orientation of cellulose and pectin in the cell wall of onion was determined by FTIR microscope [86], and the hemicellulose and pectin in the cell wall of onion also have been studied $[32,83]$. Wilson et al. [87] studied the mechanical properties and molecular dynamics of onion using FTIR. Besides onion, woody biomass also has been investigated for structural information via FTIR [65]. With Raman spectroscopy, FTIR has been used to investigate the changes in composition and structure of oak wood and barley straw during chemical and biochemical treatments [88]. Different spectral features were found in soft and hard woods, and the ratio of syringyl to guaiacyl lignin within one hardwood tree may vary with morphological location and cell type, possibly indicating that different strategies should be employed for lignocellulosic biomass [65].

Studying the biomass materials for compositional analysis using FTIR has attracted much attention and shows promise. The chemometric analysis methods used in NIR also could be applied to FTIR analysis. Tucker et al. [30] used FTIR-PLS to determine the composition of pretreated softwood and suggested that the correlation coefficients for glucose and lignin were over 0.9 , but the coefficients for the other components were low. Similar to the data analysis in NIR study, Tamaki and Mazza [89] employed FTIR-PLS to investigate carbohydrate content and lignin as well as extractives, and the results showed good or excellent predictive ability [90]. Along with PCA, FTIR was used for investigating the fine structural features of arabinoxylan in wheat, although the removal of starch was necessary because of its overlapped bands with arabinoxylan [91]. Allison et al. [92] suggested that nitrogen content and alkali index in energy grass could be predicted accurately with FTIR-PLS. He and his co-workers also found that the composition of acid detergent lignin, total hydroxycinnamic acid, total ferulate monomers plus dimers, $p$-coumarate, and ferulate dimers could be predicted with FTIR-PLS [93]. 
With multivariate linear regression, FTIR could not only provide structural information, but also predict biomass digestibility as well as sugar yield after enzymatic hydrolysis. For example, FTIR was used to predict the sugar yield of AFEX(ammonia fiber explosion)-treated rice straw after enzymatic hydrolysis [94], indicating that a fast method is available for evaluation of pretreatment efficiency. Also, a recent study using FTIR-PLS regression accurately predicted glucose and xylose conversions [19].

In addition to compositional determination, FTIR has been used to study the crystalline structure of biomass. An empirical "crystallinity index" for native cotton was established [95]. The lateral order index $\left(\alpha_{1429 / 893}\right)$ and hydrogen-bond intensity $\left(\alpha_{3336 / 1336}\right)$ could be used for qualitative analysis of crystallinity change [96]. However, this method is not applicable to mercerized cotton. In addition, dynamic FTIR was used to study cellulose allomorph I composition in pulp samples [97]. The changes in crystalline structure of cellulose II also were observed with FTIR at the supermolecular and molecular level [98].

\section{Summary}

- The tremendous amount of information about biomass structure from IRS analysis provides both qualitative and quantitative results.

- Traditional composition analysis using wet chemical methods is labor-intensive and time-consuming, and thus does not meet industrial requirements for providing quick measurements. IRS techniques promise fast, accurate, and low-cost analytical methods.

- Statistical tools are important companions of IRS techniques, which provide robust models to predict the structural information of biomass.

- Investigation of IRS on biomass is in development, and efforts have been made to promote IRS as practical in biomass processing.

- IRS techniques could be used with other analyses of characterization, such as X-ray diffraction and nuclear magnetic resonance, for better understanding of biomass structure.

\section{Acknowledgements}

This work was supported by Agriculture and Food Research Initiative Competitive Grant 2011-03587 from the US Department of Agriculture National Institute of Food and Agriculture. This is contribution number 13-016-J from the Kansas Agricultural Experiment Station.

\section{References}

[1] Binder JB, Raines RT. Simple chemical transformation of lignocellulosic biomass into furans for fuels and chemicals. J Am Chem Soc 2009;131:1979-85.

[2] Xu F, Shi YC, Wang D. Enhanced production of glucose and xylose with partial dissolution of corn stover in ionic liquid, 1-Ethyl-3-methylimidazolium acetate. Bioresour Technol 2012;114:720-4.

[3] Chen WH, Tu YJ, Sheen HK. Disruption of sugarcane bagasse lignocellulosic structure by means of dilute sulfuric acid pretreatment with microwaveassisted heating. Appl Energy 2011;88:2726-34.

[4] Sigurbjornsdottir MA, Orlygsson J. Combined hydrogen and ethanol production from sugars and lignocellulosic biomass by Thermoanaerobacterium AK 54, isolated from hot spring. Appl Energy 2011;97:785-91.

[5] El Mansouri N, Pizzi A, Salvadó J. Lignin-based wood panel adhesives without formaldehyde. Eur J Wood \& Wood Prod 2007;65:65-70.

[6] El Mansouri NE, Yuan Q. Huang F. Characterization of alkaline lignins for use in phenol-formaldehyde and epoxy resins. BioResources 2011;6:2647-62.

[7] Nishida M, Uraki Y, Sano Y. Lignin gel with unique swelling property. Bioresour Technol 2003;88:81-3.
[8] Parajuli D, Adhikari CR, Kuriyama M, Kawakita H, Ohto K, Inoue K, et al. Selective recovery of gold by novel lignin-based adsorption gels. Ind \& Eng Chem Res 2006;45:8-14.

[9] Siracusa V, Rocculi P, Romani S, Rosa MD. Biodegradable polymers for food packaging: a review. Trends Food Sci Technol 2008;19:634-43.

[10] Zhang K, Johnson L, Nelson R, Yuan W, Pei Z, Wang D. Chemical and elemental composition of big bluestem as affected by ecotype and planting location along the precipitation gradient of the great plains. Ind Crops Prod 2012;40:210-8

[11] Agbor VB, Cicek N, Sparling R, Berlin A, Levin DB. Biomass pretreatment: Fundamentals toward application. Biotechnol Adv 2011;29:675.

[12] Xu F, Shi YC, Wang D. Towards understanding structural changes of photoperiod-sensitive sorghum biomass during sulfuric acid pretreatment. Bioresour Technol.; 2012. <http://dx.doi.org/10.1016/j.biortech.2012.08.141>.

[13] Sluiter JB, Ruiz RO, Scarlata CJ, Sluiter AD, Templeton DW. Compositional analysis of lignocellulosic feedstocks. 1. Review and description of methods. J Agric Food Chem 2010;58:9043-53.

[14] Templeton DW, Scarlata CJ, Sluiter JB, Wolfrum EJ. Compositional analysis of lignocellulosic feedstocks. 2. Method uncertainties. J Agric Food Chem 2010;58:9054-62.

[15] Sluiter A, Hames B, Ruiz R, Scarlata C, Sluiter J, Templeton D, et al. Determination of structural carbohydrates and lignin in biomass. Golden, CO: NREL; 2004.

[16] Hames BR, Thomas SR, Sluiter AD, Roth CJ, Templeton DW. Rapid biomass analysis. Appl Biochem Biotechnol 2003;105:5-16.

[17] DeMartini JD, Studer MH, Wyman CE. Small-scale and automatable highthroughput compositional analysis of biomass. Biotechnol Bioeng 2011;108:306-12.

[18] Hames B, Ruiz R, Scarlata C, Sluiter A, Sluiter J, Templeton D. Preparation of samples for compositional analysis. Biomass analysis technology team Laboratory analytical procedure National Renewable energy Laboratory Version; 2004:p. 1-9.

[19] Sills DL, Gossett JM. Using FTIR to predict saccharification from enzymatic hydrolysis of alkali pretreated biomasses. Biotechnol Bioeng 2012;109:353-62.

[20] Qiu P, Ding H, Tang Y, Xu R. Determination of chemical composition of commercial honey by near-infrared spectroscopy. J Agric Food Chem 1999;47:2760-5.

[21] Huang H, Yu H, Xu H, Ying Y. Near infrared spectroscopy for on/in-line monitoring of quality in foods and beverages: A review. J Food Eng 2008;87:303-13.

[22] Roggo Y, Chalus P, Maurer L, Lema-Martinez C, Edmond A, Jent N. A review of near infrared spectroscopy and chemometrics in pharmaceutical technologies. J Pharm Biomed Anal 2007;44:683-700.

[23] Paschalis EP, Mendelsohn R, Boskey AL. Infrared assessment of bone quality: a review. Clin Orthopaedics Relat Res 2011;469:2170-8.

[24] Lanza E. Determination of moisture, protein, fat, and calories in raw pork and beef by near infrared spectroscopy. J Food Sci 1983;48:471-4.

[25] Delwiche SR. Single wheat kernel analysis by near-infrared transmittance. protein content. Cereal Chem 1995;72:11-6.

[26] Delwiche SR, Pierce RO, Chung OK, Seabourn BW. Protein content of wheat by near-infrared spectroscopy of whole grain: Collaborative study. J AOAC Int 1998;81:587-603.

[27] Saranwong S, Sornsrivichai J, Kawano S. Prediction of ripe-stage eating quality of mango fruit from its harvest quality measured nondestructively by near infrared spectroscopy. Postharvest Biol Technol 2004;31:137-45.

[28] Wardlab. Nebraska. Ward Laboratories, Inc. [Cited: 2012 Novermber 30]. <http://www.wardlab.com/FeeSchedule/FeedAnalysis.aspx>.

[29] Liebmann B, Friedl A, Varmuza K. Applicability of near-infrared spectroscopy for process monitoring in bioethanol production. Biochem Eng J 2010;52:187-93.

[30] Tucker MP, Nguyen QA, Eddy FP, Kadam KL, Gedvilas LM, Webb JD. Fourier transform infrared quantitative analysis of sugars and lignin in pretreated softwood solid residues. Appl Biochem Biotechnol 2001;91:51-61.

[31] Liu Q, Zhong Z, Wang S, Luo Z. Interactions of biomass components during pyrolysis: A TG-FTIR study. J Anal Appl Pyrolysis 2011;90:213-8.

[32] McCann MC, Hammouri M, Wilson R, Belton P, Roberts K. Fourier transform infrared microspectroscopy is a new way to look at plant cell walls. Plant Physiol 1992;100:1940.

[33] Chipara M, Hamilton J, Chipara AC, George T, Chipara DM, Ibrahim EE, et al. Fourier transform infrared spectroscopy and wide-angle X-ray scattering: Investigations on polypropylene-vapor-grown carbon nanofiber composites. J Appl Polym Sci 2012.

34] Miller CE. Chemical principles of near infrared technology. In: Williams P, Norris K, editors. Near infrared technology in the agricultural and food industries. St. Paul, Minnesota, USA: American Association of Cereal Chemists, Inc.; 2001. p. 19-37.

[35] McClure WF. Near-Infrared instrumentation. In: Williams P, Norris K, editors. Near infrared technology in the agricultural and food industries. St. Paul, Minnesota, USA: American Association of Cereal Chemists, Inc.; 2001. p. 109-28.

[36] Cozzolino D, Smyth HE, Gishen M. Feasibility study on the use of visible and near-infrared spectroscopy together with chemometrics to discriminate between commercial white wines of different varietal origins. J Agric Food Chem 2003;51:7703-8. 
[37] Wetterlind J, Stenberg B, Söderström M. The use of near infrared (NIR) spectroscopy to improve soil mapping at the farm scale. Precision Agric 2008;9:57-69.

[38] Wetzel DL, LeVine SM. Imaging molecular chemistry with infrared microscopy. Science 1999;285:1224

[39] Ma H, Anderson CA. Characterization of pharmaceutical powder blends by NIR chemical imaging. J Pharm Sci 2007;97:3305-20.

[40] Camacho N, West P, Griffith M, Warren R, Hidaka C. FT-IR imaging spectroscopy of genetically modified bovine chondrocytes. Mater Sci Eng C $2001 ; 17: 3-9$.

[41] Weinstock BA, Janni J, Hagen L, Wright S. Prediction of oil and oleic acid concentrations in individual corn (Zea mays L.) kernels using near-infrared reflectance hyperspectral imaging and multivariate analysis. Appl Spectrosc 2006;60:9-16

[42] Gierlinger N, Goswami L, Schmidt M, Burgert I, Coutand C, Rogge T, et al. In situ FT-IR microscopic study on enzymatic treatment of poplar wood crosssections. Biomacromolecules 2008;9:2194-201.

[43] Giddings T, Brower D, Staehelin L. Visualization of particle complexes in the plasma membrane of Micrasterias denticulata associated with the formation of cellulose fibrils in primary and secondary cell walls. J Cell Biol 1980;84:327

[44] Hernandez-Blanco C, Feng D, Hu J, Sanchez-Vallet A, Deslandes L, Llorente F, et al. Impairment of cellulose synthases required for Arabidopsis secondary cell wall formation enhances disease resistance. Plant Cell Online 2007; $19: 890$.

[45] Gutiérrez A, del Río JC, Martínez AT. Microbial and enzymatic control of pitch in the pulp and paper industry. Appl Microbiol Biotechnol 2009;82:1005-18.

[46] Kraessig H. Cellulose: structure, accessibility, and reactivity. CRC; 1993.

[47] Zugenmaier P. Conformation and packing of various crystalline cellulose fibers. Prog Polym Sci 2001;26:1341-417.

[48] Sugiyama J, Persson J, Chanzy H. Combined infrared and electron diffraction study of the polymorphism of native celluloses. Macromolecules 1991;24:2461-6.

[49] Kondo T, Sawatari C. A Fourier transform infra-red spectroscopic analysis of the character of hydrogen bonds in amorphous cellulose. Polymer 1996;37:393-9.

[50] Hinterstoisser B, Åkerholm M, Salmén L. Load distribution in native cellulose. Biomacromolecules 2003;4:1232-7.

[51] Somerville C, Bauer S, Brininstool G, Facette M, Hamann T, Milne J, et al. Toward a systems approach to understanding plant cell walls. Science 2004;306:2206-11.

[52] Kacurakova M, Capek P, Sasinkova V, Wellner N, Ebringerova A. FT-IR study of plant cell wall model compounds: pectic polysaccharides and hemicelluloses. Carbohydr Polym 2000:43:195-203.

[53] Shen D, Gu S, Bridgwater AV. Study on the pyrolytic behaviour of xylan-based hemicellulose using TG-FTIR and Py-GC-FTIR. J Anal Appl Pyrolysis 2010;87:199-206.

[54] Whetten R, MacKay J, Sederoff R. Recent advances in understanding lignin biosynthesis. Annu Rev Plant Biol 1998;49:585-609.

[55] Eriksson T, Börjesson J, Tjerneld F. Mechanism of surfactant effect in enzymatic hydrolysis of lignocellulose. Enzyme Microb Technol 2002;31:353-64.

[56] Shevchenko SM, Beatson RP, Saddler JN. The nature of lignin from steam explosion/enzymatic hydrolysis of softwood. Appl Biochem Biotechnol 1999;79:867-76.

[57] Giger-Reverdin S. Review of the main methods of cell wall estimation: interest and limits for ruminants. Anim Feed Sci Technol 1995;55:295-334.

[58] Kubo S, Kadla JF. Hydrogen bonding in lignin: a Fourier transform infrared model compound study. Biomacromolecules 2005;6:2815-21.

[59] Tsuchikawa S. A review of recent near infrared research for wood and paper. Appl Spectrosc Rev 2007;42:43-71.

[60] Wetzel DL. Contemporary near-Infrared instrumentation. In: Williams P, Norris K, editors. Near infrared technology in the agricultural and food industries. St. Paul, Minnesota, USA: American Association of Cereal Chemists, Inc.; 2001. p. 129-44.

[61] Liu L, Ye XP, Womac AR, Sokhansanj S. Variability of biomass chemical composition and rapid analysis using FT-NIR techniques. Carbohydr Polym 2010;81:820-9.

[62] Michell A, Schimleck L. NIR spectroscopy of woods from Eucalyptus globulus. Appita J 1996;49:23-6.

[63] Axrup L, Markides K, Nilsson T. Using miniature diode array NIR spectrometers for analysing wood chips and bark samples in motion. J Chemometrics 2000;14:561-72.

[64] Martens H, Naes T. Multivariate calibration by data compression. In: Williams $\mathrm{P}$, Norris K, editors. Near infrared technology in the agricultural and food industries. St. Paul, Minnesota, USA: American Association of Cereal Chemists, Inc.; 2001. p. 59-69.

[65] Owen N, Thomas D. Infrared studies of "hard" and "soft" woods. Appl Spectrosc 1989;43:451-5.

[66] Chen H, Ferrari C, Angiuli M, Yao J, Raspi C, Bramanti E. Qualitative and quantitative analysis of wood samples by Fourier transform infrared spectroscopy and multivariate analysis. Carbohydr Polym 2010;82:772-8.

[67] Hruschka WR. Data analysis: wavelength selection methods. In: Williams P, Norris K, editors. Near infrared technology in the agricultural and food industries. St. Paul, Minnesota, USA: American Association of Cereal Chemists, Inc.; 2001. p. 39-58.
[68] Michell AJ. Pulpwood quality estimation by near-infrared spectroscopic measurements on eucalypt woods. Appita J 1995;48:425-8.

[69] Cozzolino D, Fassio A, Gimenez A. The use of near-infrared reflectance spectroscopy NIRS to predict the composition of whole maize plants. J Sci Food Agric 2001;81:142-6.

[70] Miralbés C. Prediction chemical composition and alveograph parameters on wheat by near-infrared transmittance spectroscopy. J Agric Food Chem 2003;51:6335-9.

[71] Jin S, Chen H. Near-infrared analysis of the chemical composition of rice straw. Ind Crops Prod 2007;26:207-11.

[72] Ziemons E, Mantanus J, Lebrun P, Rozet E, Evrard B, Hubert P. Acetaminophen determination in low-dose pharmaceutical syrup by NIR spectroscopy. Pharm Biomed Anal 2010;53:510.

[73] Thygesen LG. Determination of dry matter content and basic density of Norway spruce by near infrared reflectance and transmittance spectroscopy. J Near Infrared Spectrosc 1994;2:127-35.

[74] Hoffmeyer P, Pedersen J. Evaluation of density and strength of Norway spruce wood by near infrared reflectance spectroscopy. Eur J Wood \& Wood Prod 1995;53:165-70.

[75] Kelley SS, Rials TG, Snell R, Groom LH, Sluiter A. Use of near infrared spectroscopy to measure the chemical and mechanical properties of solid wood. Wood Sci Technol 2004;38:257-76.

[76] Lestander TA, Rhén C. Multivariate NIR spectroscopy models for moisture, ash and calorific content in biofuels using bi-orthogonal partial least squares regression. Analyst 2005;130:1182-9.

[77] Labbé N, Lee SH, Cho HW, Jeong MK, André N. Enhanced discrimination and calibration of biomass NIR spectral data using non-linear kernel methods. Bioresour Technol 2008;99:8445-52.

[78] Templeton DW, Sluiter AD, Hayward TK, Hames BR, Thomas SR. Assessing corn stover composition and sources of variability via NIRS. Cellulose 2009;16:621-39.

[79] Wolfrum EJ, Sluiter AD. Improved multivariate calibration models for corn stover feedstock and dilute-acid pretreated corn stover. Cellulose 2009;16:567-76.

[80] Hou S, Li L. Rapid characterization of woody biomass digestibility and chemical composition using near infrared spectroscopy. J Integrative Plant Biol 2011:53:166-75.

[81] Sanderson MA, Agblevor F, Collins M, Johnson DK. Compositional analysis of biomass feedstocks by near infrared reflectance spectroscopy. Biomass Bioenergy 1996:11:365-70.

[82] Philip Ye X, Liu L, Hayes D, Womac A, Hong K, Sokhansanj S. Fast classification and compositional analysis of cornstover fractions using Fourier transform near-infrared techniques. Bioresour Technol 2008;99:7323-32.

[83] Sene CFB, McCann MC, Wilson RH, Grinter R. Fourier-transform Raman and Fourier-transform infrared spectroscopy (an investigation of five higher plant cell walls and their components). Plant Physiol 1994;106:1623-31

[84] Smith-Moritz AM, Chern M, Lao J, Sze-To WH, Heazlewood JL, Ronald PC, et al. Combining multivariate analysis and monosaccharide composition modeling to identify plant cell wall variations by Fourier Transform Near Infrared spectroscopy. Plant Methods 2011;7:26.

[85] Mouille G, Robin S, Lecomte M, Pagant S, Höfte H. Classification and identification of Arabidopsis cell wall mutants using Fourier-Transform InfraRed (FT-IR) microspectroscopy. Plant J 2003;35:393-404.

[86] Chen L, Wilson RH, McCann MC. Investigation of macromolecule orientation in dry and hydrated walls of single onion epidermal cells by FTIR microspectroscopy. J Mol Struct 1997;408:257-60.

[87] Wilson RH, Smith AC, Kačuráková M, Saunders PK, Wellner N, Waldron KW. The mechanical properties and molecular dynamics of plant cell wall polysaccharides studied by Fourier-transform infrared spectroscopy. Plant Physiol 2000;124:397-406.

[88] Stewart D, Wilson H, Hendra P, Morrison I. Fourier-transform infrared and Raman spectroscopic study of biochemical and chemical treatments of oak wood (Quercus rubra) and barley (Hordeum vulgare) straw. J Agric Food Chem 1995:43:2219-25.

[89] Tamaki Y, Mazza G. Rapid determination of carbohydrates, ash, and extractives contents of straw using attenuated total reflectance Fourier transform mid-infrared spectroscopy. J Agric Food Chem 2011;59:6346-52.

[90] Tamaki Y, Mazza G. Rapid determination of lignin content of straw using Fourier Transform Mid-Infrared Spectroscopy. J Agric Food Chem 2011:59:504-12.

[91] Robert P, Marquis M, Barron C, Guillon F, Saulnier L. FT-IR investigation of cell wall polysaccharides from cereal grains. Arabinoxylan infrared assignment. J Agric Food Chem 2005;53:7014-8.

[92] Allison GG, Morris C, Hodgson E, Jones J, Kubacki M, Barraclough T, et al Measurement of key compositional parameters in two species of energy grass by Fourier transform infrared spectroscopy. Bioresour Techno 2009;100:6428-33.

[93] Allison GG, Thain SC, Morris P, Morris C, Hawkins S, Hauck B, et al. Quantification of hydroxycinnamic acids and lignin in perennial forage and energy grasses by Fourier-transform infrared spectroscopy and partial least squares regression. Bioresour Technol 2009;100:1252-61.

[94] Gollapalli LE, Dale BE, Rivers DM. Predicting digestibility of ammonia fiber explosion (AFEX)-treated rice straw. Appl Biochem Biotechnol 2002;98:23-35. 
[95] O’Connor RT, DuPré EF, Mitcham D. Applications of infrared absorption spectroscopy to investigations of cotton and modified cottons. Textile Res J $1958 ; 28: 382$

[96] Kljun A, Benians TAS, Goubet F, Meulewaeter F, Knox JP, Blackburn RS Comparative analysis of crystallinity changes in cellulose I polymers using ATR-FTIR, X-ray diffraction, and carbohydrate-binding module (CBM) probes. Biomacromolecules 2011;12:4121-6.

[97] Åkerholm M, Hinterstoisser B, Salmén L. Characterization of the crystalline structure of cellulose using static and dynamic FT-IR spectroscopy. Carbohydr Res 2004;339:569-78.

[98] Široký J, Blackburn RS, Bechtold T, Taylor J, White P. Attenuated tota reflectance Fourier-transform Infrared spectroscopy analysis of crystallinity changes in lyocell following continuous treatment with sodium hydroxide. Cellulose 2010;17:103-15.

[99] Baillères H, Davrieux F, Ham-Pichavant F. Near infrared analysis as a tool for rapid screening of some major wood characteristics in a eucalyptus breeding program. Annal Forest Sci 2002;59:479-90.

[100] McLellan TM, Aber JD, Martin ME, Melillo JM, Nadelhoffer KJ. Determination of nitrogen, lignin, and cellulose content of decomposing leaf material by near infrared reflectance spectroscopy. Can J Forest Res 1991;21:1684-8.

[101] Ono K, Hiraide M, Amari M. Determination of lignin, holocellulose, and organic solvent extractives in fresh leaf, litterfall, and organic material on forest floor using near-infrared reflectance spectroscopy. J Forest Res 2003;8:191-8.
[102] Zhou G, Taylor G, Polle A. FTIR-ATR-based prediction and modelling of lignin and energy contents reveals independent intra-specific variation of these traits in bioenergy poplars. Plant Methods 2011;7:9.

[103] Nkansah K, Dawson-Andoh B, Slahor J. Rapid characterization of biomass using near infrared spectroscopy coupled with multivariate data analysis: Part 1 yellow-poplar (Liriodendron tulipifera L.). Bioresour Technol 2010;101:4570-6.

[104] Yeh TF, Chang H, Kadla JF. Rapid prediction of solid wood lignin content using transmittance near-infrared spectroscopy. J Agric Food Chem 2004;52:1435-9.

[105] Poke FS, Wright JK, Raymond CA. Predicting extractives and lignin contents in Eucalyptus globulus using near infrared reflectance analysis. J Wood Chem Technol 2005;24:55-67.

[106] Kelley SS, Rowell RM, Davis M, Jurich CK, Ibach R. Rapid analysis of the chemical composition of agricultural fibers using near infrared spectroscopy and pyrolysis molecular beam mass spectrometry. Biomass Bioenergy 2004;27:77-88.

[107] Liu X, Han L. Evaluation of near-infrared reflectance spectroscopy (NIRS) for predicting chemical composition of straw silage. J Anim Feed Sci 2006;15:329.

[108] Schwanninger M, Rodrigues J, Pereira H, Hinterstoisser B. Effects of shorttime vibratory ball milling on the shape of FT-IR spectra of wood and cellulose. Vib Spectrosc 2004;36:23-40. 